\section{Lt Colonel Charles Leofric Boyle OBE: 1899-1999}

Leofric Boyle, secretary of the (then) Fauna Preservation Society (FPS) from 1950 to 1963, died on 21 March at the commendable age of 100 . Although he had been a career officer in the Army, reaching the rank of lieutenantcolonel and serving for 30 years, he then achieved a second career by bringing a zest to conservation in general and, even more precisely, to the society. This flowering of a different enthusiasm was no chance occurrence. He had always been fascinated by wildlife, notably birds, and he had leapt to the opportunity to work on its behalf once retirement from the Army had become a fact.

He was born in southern India, where his father worked as a professor in English. He was christened Charles Leofric Boyle, but the Charles was never used because that was also his father's name. As for Leofric, which was never abbreviated in any way, that distinguished title was also the name of Lady Godiva's husband, and plainly an English professor was exercising some happy whim. Unfortunately, that father died when Leofric was only 3 years old, causing the remainder of the family to move back to England.

Without doubt, an interest in natural history started early with Leofric Boyle. As one indication, an aunt gave him a formidably adult book, British Butterflies and Moths, on his fifth birthday, with aunts then not necessarily user-friendly but terribly well intentioned. After education at King's School, Canterbury, he entered the Royal Military Academy at Woolwich, before being commissioned into the Royal Artillery. His military duties took him to Ireland, Jamaica and India. The sea journeys these entailed, lengthily back and forth, proved to be excellent opportunities for observing birds, and the impressive fauna of India was an extra stimulant.

In 1950, the year also of his second marriage (with that honeymoon spent bird-watching at Cley in Norfolk), he started work with the old FPS, finding it 'somewhat stuffy'. There also did not seem much for him to do. He therefore became a frequent visitor to London's Heathrow airport where he took great interest in the numbers, species and welfare of incoming animals. From this work arose, although in infant form in its early days, the organization now known as the Convention on International Trade in Endangered Species of Wild Fauna and Flora. In 1957 he visited Africa, realized that the new dam being built on the Zambesi would cause trouble, and organized Operation Noah. This attempt to rescue imperilled wildlife did much to help and publicize the cause of conservation.
Next, among his major schemes, came Operation Oryx. He had heard that the Arabian oryx was in terrible trouble, and recruited Ian Grimwood, then chief game warden in Kenya, to become leader of a rescue mission. This proved to be a triumph, with three animals captured and taken to Phoenix in Arizona, where they bred well in that similar climate, created other groups, and eventually built up sufficient numbers so that some animals could be sent back, with greater protection then possible, to their former range and habitat.

The old, brown-coloured, and laggard Journal of the Society for the Preservation of the Fauna of the Empire then had its name changed to Ory $x$ and has never looked back. Similarly, Boyle's society adopted the oryx, with its striking horns, as its forthright logo. Part of his work is therefore enshrined, with capturings and reintroductions not always so successful or so well remembered. For his conservation work, notably in connection with a parliamentary bill concerning the importation of endangered species, he was appointed OBE in 1963. Ten years later he received the Order of the Golden Ark from Prince Bernhard of the Netherlands.

Upon retirement from the Society he remained unceasingly active. He continued to serve the unending task of conservation, by working with the RSPCA, by editing its Book of British Mammals, by writing articles or letters whenever he felt that there was need, and he steadfastly refused to let mere old age get in the way of living. As a near neighbour I generally saw him wheeling his bicycle, laden with planks of wood and other goodies filched from handy skips to fulfil some purpose at his home. For seekers after longevity that is plainly a policy to be recommended. I also met him at the old FPS offices, just past the big bird aviary in London Zoo. He and a particular fish eagle would often engage in happy chat, each with head held back and uttering, I will swear, the self-same cry.

Yes, he did receive an (unsigned) notification from the Queen on his final birthday, and 70 people gathered to honour him and his long life. He leaves behind him many happy memories, as well as his second wife Valerie, four daughters from his first marriage, 10 grandchildren, 17 great-grandchildren, and even one great-great-granddaughter. There is also Fauna \& Flora International, as well as this journal, which both owe him much for his spirited labours that served them so well. (A memorial service of thanksgiving for the life of Lieutenant Colonel Charles Leofric Boyle OBE was held at St Saviour's Church, Eton Road, Hampstead on 18 April 1999.)

Anthony Smith 